\title{
Analisa Pengiriman Citra Terkompresi SPIHT dengan Teknik Spread Spectrum Direct Sequence (DS-SS)
}

\author{
Nia Maulidia \\ Jurusan Teknik Informatika \\ Politeknik Negeri Jakarta \\ Depok, Indonesia \\ niamaulidia1@gmail.com
}

Diterima: 11 Maret 2015. Disetujui: 28 April 2015. Dipublikasikan: Mei 2015

\begin{abstract}
Abstrak - Pada era teknologi informasi saat ini permintaan akan kebutuhan komunikasi multimedia terus meningkat. Situs web di internet dibuat semenarik mungkin dengan menyertakan visualisasi berupa gambar atau video yang dapat diputar. Citra (image) sebagai salah satu komponen multimedia memegang satu peranan sangat penting sebagai bentuk informasi visual. File citra memiliki kapasitas yang cukup besar, dan untuk mengaksesnya dibutuhkan waktu yang lama, sehingga dibutuhkan sebuah teknik kompresi data, dengan tujuan untuk mengurangi redudansi dari data-data yang terdapat dalam file citra, sehingga file citra dapat disimpan atau ditransmisikan secara efisien. Dalam hal ini file citra akan dikompresi dengan menggunakan algoritma SPIHT (Set Partitioning In Hierarchical Trees), SPIHT merupakan algoritma kompresi citra yang mampu mencapai rasio kompresi yang tinggi. Dengan cara mengkodekan koefisien hasil transformasi wavelet secara bertahap, dikarenakan aliran data terkompresi sangat rentan terhadap gangguan kanal. Pada proses transmisi digunakan teknik Direct Sequence Spread Spektrum (DS-SS). Hasil yang didapat setelah simulasi, berupa citra-citra rekonstruksi yang diukur dengan parameter penilaian obyektif yang berdasarkan nilai Peak Signal to Noise Ratio. Penilaian obyektif kualitas citra rekonstruksi yang efisien dengan rate $2 \mathrm{bpp}$ diperoleh nilai PSNR 46.834 dB.
\end{abstract}

Kata Kunci: kompresi, SPIHT, wavelet, DSSS, rate, PSNR.

\section{PENDAHULUAN}

Seiring dengan berkembangnya teknologi digital saat ini, dengan banyaknya peralatan digital yang dapat ditemui dalam kehidupan sehari-hari seperti komputer, kamera digital, handphone dan sebagainya. hal ini menyebabkan terjadinya peningkatan yang cukup pesat terhadap permintaan kebutuhan komunikasi data digital, data atau informasi tidak hanya disajikan dalam bentuk teks, tetapi juga dapat berbentuk gambar, audio, dan video, atau yang sering disebut dengan sebagai multimedia. Dan salah satu yang cukup banyak diminati adalah pengolahan citra digital. Dibandingkan dengan data teks, citra mempunyai karakteristik tersendiri, yaitu citra merupakan data yang kaya dengan informasi. Bahkan ada sebuah istilah yang cukup popular yaitu "a picture is more than a thousand words" yang berarti bahwa sebuah gambar dapat memberikan informasi yang lebih banyak jika dibandingkan dengan informasi yang disajikan dalam bentuk kata-kata atau tulisan.Tetapi pada sebuah gambar digital mempunyai kapasitas atau ukuran yang cukup besar, jika disimpan akan membutuhkan memori yang besar untuk menyimpan data tersebut, mengingat media penyimpanan sangatlah terbatas, dan jika harus di kirim maka akan dibutuhkan waktu yang cukup lama dalam proses pentransmisian. Salah satu solusinya adalah dengan cara mengkompresi data citra tersebut. Dengan kompresi citra jumlah bit yang relatif sedikit sehingga transmisi citra dapat berjalan lebih cepat. Pada umumnya transmisi citra tidak memerlukan detail yang cukup tinggi, sehingga diperlukan sedikit bit saja yang merepresentasikan sebuah citra.

Dalam pentransmisian citra, diperlukan sebuah metode tertentu agar diperoleh kualitas citra yang sesuai dengan yang diinginkan, tetapi dengan jumlah bit yang ditransmisikan kecil. Kompresi citra digital bekerja dengan cara mencari pola-pola perulangan atau biasa disebut dengan redudansi pada data dan menggantinya dengan sebuah penanda tertentu. Kompresi dilakukan dengan tujuan mengurangi redundansi dari data-data yang terdapat dalam citra sehingga dapat disimpan atau ditransmisikan secara efisien.

Metode kompresi citra mempunyai beberapa algoritma, antara lain adalah PNG, GIF dan JPEG. Beberapa diantaranya menggunakan transformasi seperti DCT (Discrete Cosine Transform) maupun DWT (Discrete Wavelet Transform). DWT 
mempunyai kemampuan mengelompokan energi citra terkosentrasi pada sekelompok kecil koefisien, mampu memberikan kombinasi informasi frekuensi dan skala, sehingga lebih akurat dalam rekonstruksi citra. Salah satu metode kompresi yang memanfaatkan transformasi wavelet adalah SPIHT (Set Partitioning in Herarcical Tress) merupakan salah satu algoritma kompresi citra yang mampu mencapai rasio kompresi yang tinggi. Dengan cara mengkodekan koefisien hasil transformasi wavelet secara bertahap. Algoritma ini bekerja dengan cara mengolah kesamaan turunan antar sub-band dalam dekompresi wavelet pada citra, sehingga mampu mencapai kompresi yang maksimal [1].

Dikarenakan aliran data terkompresi sangat rentan terhadap gangguan kanal pada proses transmisi digunakan teknik Direct Sequence Spread Spectrum (DS-SS). Spread Spectrum digunakan karena pada sistem ini, sinyal yang yang dikirimkan memiliki bandwidth yang jauh lebih lebar dari bandwidth sinyal informasinya sendiri. DS-SS menggabungkan sinyal data pada stasiun pengirim dengan suatu data rate bit sequence yang lebih tinggi, yang dikenal sebagai processing gain. Processing gain yang tinggi akan meningkatkan tahanan sinyal terhadap interferensi.

\section{TEORI PENUNJANG}

\section{A. Citra}

Citra adalah representasi dari sebuah objek. Citra merupakan fungsi continue dari intensitas cahaya pada bidang dwimatra (2D). Ada dua jenis citra yaitu : citra diam dan citra bergerak. Citra diam adalah citra tunggal yang tidak bergerak, sedangkan citra bergerak adalah rangkaian citra diam yang ditampilkan secara sekuensial.

Menurut presisi yang digunakan untuk menyatakan titik-titik kordinat pada domain spatial (bidang), dan untuk menyatakan nilai keabuan atau warna dari suatu citra, maka secara teoritis citra dapat dikelompokkan menjadi empat kelas, yaitu : citra kontinu-kontinu, kontinu-diskrit, diskritkontinu, dan diskrit-diskrit. Dimana label pertama menyatakan presisi dari titik-titik koordinat pada bidang citra, sedangkan label kedua menyatakan presisi nilai keabuan atau warna. Kontinu dinyatakan dengan presisi angka tak terhingga, sedangkan diskrit dinyatakan dengan presisi angka terhingga. Komputer digital bekerja dengan angkaangka presisi terhingga. Dengan demikian, hanya citra dari kelas diskrit yang dapat diolah oleh komputer. Citra dari kelas tersebut lebih dikenal dengan citra digital.

Terjemahan bebas dari bitmap adalah pemetaan bit. Artinya, nilai intensitas pixel di dalam citra dipetakan ke sejumlah bit tertentu. Peta bit yang umum adalah 8 , artinya setiap pixel panjangnya 8 bit. Delapan bit ini merepresentasikan nilai intensitas pixel. Dengan demikian ada sebanyak $28=256$ derajat keabuan, mulai dari 0 sampai 255[2].

\section{B. Transformasi Wavelet}

Transformasi wavelet mulai diperkenalkan pada tahun 1980-an oleh Morlet dan Grossman sebagai fungsi matematis untuk merepresentasikan data atau fungsi sebagai alternatif transformasitransformasi matematika yang lahir sebelumnya untuk menangani masalah resolusi. Sebuah wavelet merupakan gelombang singkat (small wave) yang energinya terkonsentrasi pada suatu selang waktu untuk memberikan kemampuan analisis transien, ketidakstasioneran, atau fenomena berubah terhadap waktu (time varying). Karakteristik dari wavelet antara lain adalah berosilasi singkat, translasi (pergeseran), dan dilatasi (skala).

Transformasi wavelet memiliki kemampuan untuk menganalisis suatu data dalam domain waktu dan domain frekuensi secara simultan. Wavelet dapat digunakan sebagai alat bantu matematis untuk melakukan dekomposisi suatu sinyal, seperti audio dan citra, menjadi komponen-komponen frekuensi yang berbeda sehingga masing-masing komponen tersebut dapat dipelajari dengan menggunakan skala resolusi yang sesuai. Oleh sebab itu wavelet dikenal sebagai alat untuk melakukan analisis berdasarkan skala. Tahap pertama analisis wavelet adalah menentukan tipe wavelet yang akan digunakan. Hal ini perlu dilakukan karena fungsi wavelet yang bervariasi dan dikategorikan berdasarkan fungsi dasar masing-masing jenis. Setelah dilakukan pemilihan mother wavelet, tahap selanjutnya adalah membentuk basis wavelet yang akan digunakan untuk mentrasformasikan sinyal. Suatu basis dapat dibentuk dengan mengubah nilai translasi dan dilatasi dari mather wavelet nya.

Upaya untuk merepresentasikan suatu sinyal dengan basis wavelet ini disebut Transformasi Wavelet. Dalam perhitungan koefisien dapat didapatkan dengan cara melakukan proses konvolusi dari sinyal sumber dengan salah satu jenis fungsi wavelet. Operasi terhadap suatu sinyal hanya dapat dilakukan dengan menggunakan koefisien-koefisien yang berhubungan. Analisis data pada transformasi wavelet dilakukan dengan mendekomposisikan suatu sinyal ke dalam komponen komponen frekuensi yang berbeda-beda dan selanjutnya masing-masing komponen frekuensi tersebut dapat dianalisis sesuai dengan skala resolusinya atau level dekomposisinya seperti proses filtering, dimana sinyal dalam domain waktu dilewatkan ke dalam High Pass Filter dan Low 
Pass Filter untuk memisahkan komponen frekuensi tinggi dan frekuensi rendah.

Pada bagian ini dilakukan proses dekomposisi, yakni menguraikan sinyal asli ke dalam komponen-komponen aslinya [3]. Proses dekomposisi pada 1 dimensi digambarkan pada Gambar 1.

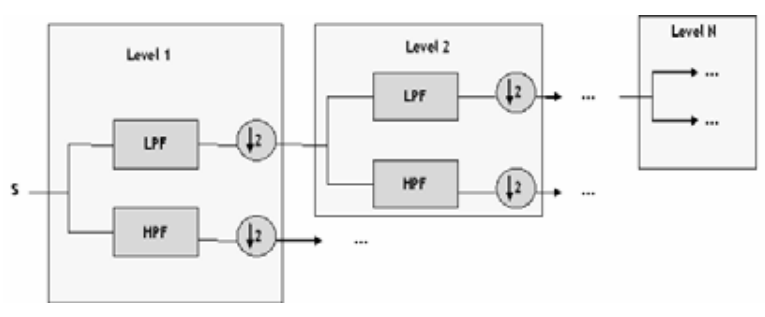

Gambar 1. Transformasi Wavelet dengan Dekomposisi Sinyal Sebanyak N kali

Pada tahap ini dilakukan proses rekonstruksi yakni proses mengembalikan kembali komponenkomponen frekuensi menjadi sinyal semula melalui proses upsampling dan pemfilteran dengan koefisien-koefisien filter balik [4]. Proses rekonstruksi pada satu dimensi digambarkan pada Gambar 2.

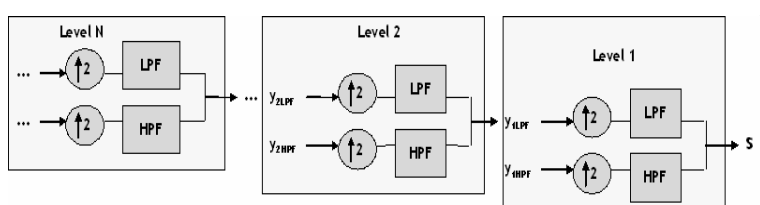

Gambar 2. Inverse Transformasi Wavelet dengan Rekonstruksi Sebanyak N kali

Dengan cara yang sama dengan proses dekomposisi dan menggunakan koefisien yang sama, proses rekonstruksi dilakukan dengan melakukan konvolusi yang kemudian diikuti oleh proses upsampling dengan faktor dua. Proses upsampling dilakukan untuk mengembalikan dan menggabungkan sinyal seperti semula [3].

\section{Kompresi SPIHT}

Algoritma SPIHT (Set Partitioning In Hierarchical Trees) diusulkan oleh Pearlman dan Said, didasarkan pada transformasi wavelet [4]. Algoritma SPIHT secara intensif menggunakan struktur data dinamis dari koefisien wavelet, untuk mengeksploitasi selfsimilarities. Hubungan parentchild pada koeffisien wavelet ditunjukkan pada Gambar 3.

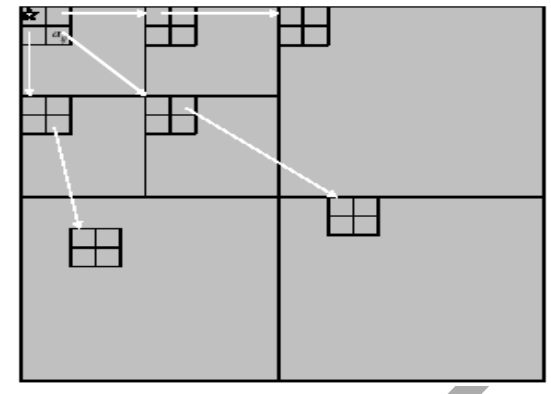

Gambar 3. Ilustrasi Hubungan Parent-Child dari Koefisien SPIHT

Pada Algorima SPIHT koefisien-koefisien diklasifikasikan kedalam tiga set, yaitu:

- LIP (list of insignificant pixel) merupakan koordinat dari koefisien yang tidak signifikan berdasarkan threshold saat ini.

- LSP (list of significant pixel) merupakan koordinat dari koefisien yang tidak signifikan berdasarkan threshold saat ini.

- LIS (list of insignificant sets) merupakan koordinat dari akar dengan subpohon yang tidak signifikan.

Selama proses kompresi, set dari koefisien pada LIS diperbaharui dan jika koefisien menjadi signifikan dipindahkan dari LIP ke LSP. Dengan demikian bitstream dapat diorganisasi secara progressif. Dengan cara yang sama set secara berurutan dievaluasi sesuai LIS, dan saat set yang ditemukan signifikan ia dihilangkan dari daftar dan dipartisi. Subset baru dengan lebih dari satu elemen ditambahkan kembali ke LIS, dengan set koordinat tunggal ditambahkan ke akhir LIP atau LSP, tergantung apakah mereka sigfikan atau tidak. Algoritma pendekodean SPIHT menggunakan metode yang sama pengkodeannya, sehingga citra dapat direkonstruksi. Karena pada proses kompresi terjadi proses pemfilteran, maka citra hasil. Rekonstruksi akan mengalami distorsi. Distorsi dinyatakan dengan Mean Square Error (MSE):

$$
M S E=\frac{1}{M N} \sum_{i=0}^{N-1} \sum_{j=0}^{M-1}\left[\left|f(i, j)-f^{\prime}(i, j)\right|^{2}\right]
$$

Kualitas citra hasil rekonstruksi dibandingkan dengan citra asal menggunakan parameter Peak Signal To Noise Ratio (PSNR). PSNR dihitung menggunakan persaman berikut:

$$
P S N R=10 \log _{10} \frac{255^{2}}{M S E^{2}}
$$

Semakin besar nilai PSNR, maka kualitas citra hasil rekonstruksi semakin baik. 
D. Sistem Transmisi Spread Spectrum Direct Sequences (DSSS)

Direct Sequence Spread Spectrum (DSSS) adalah suatu metode untuk mengirimkan data dimana sistem pengirim dan penerima keduanya berada pada set frekuensi yang lebarnya adalah 22 MHz. DSSS merupakan jenis spread spectrum yang paling luas dikenal dan paling banyak digunakan. karena sistem ini dikenal paling mudah implementasinya dan memiliki data rate yang tinggi. DSSS menggabungkan sinyal data pada stasiun pengirim dengan suatu data rate bit sequence yang lebih tinggi, yang dikenal sebagai chipping code atau processing gain. Chipping code adalah proses pengiriman data menggunakan teknologi ini melibatkan serangkaian kode penyebaran processing gain adalah rasio yang tersebar RF bandwidth ke unspread baseband bandwidth. Processing gain yang tinggi meningkatkan tahanan sinyal terhadap interferensi [6]. Gambar 4 menunjukkan proses building block.

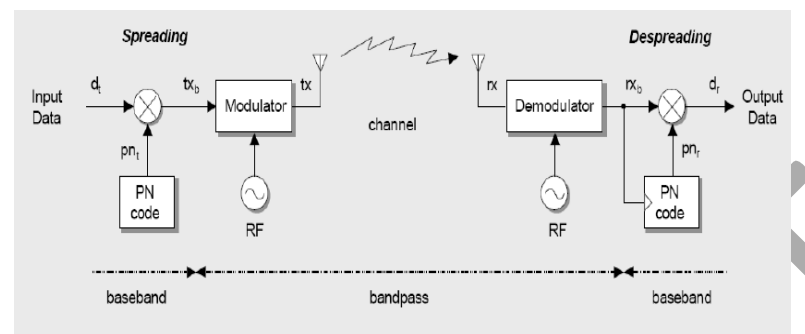

Gambar 4. Building Block dari Sistem DSSS

\section{Spreading}

Suatu data analog akan dikonversikan menjadi digital menggunakan A/D converter. Sinyal keluarannya adalah deretan sinyal digital (dt). Sinyal dt tersebut akan dipadukan dengan Pnt (PN code) sehingga akan menghasilkan sinyal Spread Spektrum (SS). Sinyal SS ini akan dipadukan dengan sinyal carrier yang ada pada modulator sehingga terjadi proses modulasi. Hasil sinyal ini berupa sinyal SS analog yang akan ditransmisikan lewat antena. Pada proses spreading digunakan perkalian XOR antara data input dengan Pn code. Akibat dari perkalian ini akan menebarkan sinyal informasi dari lebar baseband Rs data input dt menjadi lebar baseband Rc (terjadi penebaran terhadap lebar spektrum sinyal informasi menjadi lebih besar identik dengan lebar spektrum atau bandwidth Pn code).

\section{Despreading}

Proses ini adalah proses untuk memperoleh sinyal data dari sinyal SS yang diterima oleh receiver $(\mathrm{Rx})$. Sinyal analog yang diterima antenna akan didemodulasi dengan carrier pada demodulator. Keluaran dari modulator berupa sinyal SS, sinyal ini akan dipadukan dengan Pnr dimana Pnr merupakan replika dari Pnt. Sinyal yang dihasilkan adalah dt berupa sinyal digital kemudian akan dikonversikan menjadi analog (D/A) untuk dikirimkan lewat antena. Apabila Pnt $\neq$ Pnr maka hasil sinyal spreading bukanlah sinyal info melainkan hanya deretan chips. Untuk memperoleh sinyal info harus memenuhi syarat mutlak yaitu Pnt =Pnr. Sinyal spread spektrum yang dikirim tidak dapat dideteksi oleh penerima sinyal pita sempit (narrowband) karena daya sinyalnya yang lemah atau dapat dikatakan menyerupai noise. Perkalian antara sinyal yang diterima dengan kode Psnr akan menghasilkan sinyal informasi asli yang dikirim. Pengaruh dari proses despreading ini adalah merampingnya lebar band dari data spread spektrum yang dikirim ke lebar band baseband Rs sinyal informasi asli kembali.

- Pembangkit Pn Code

PN code digunakan untuk menebar sinyal informasi yang digunakan untuk membedakan pengguna satu dengan yang lainnya, dimana satuan PN code disebut chips. Penentuan PN code harus memperhatikan syarat sebagai berikut:

a. Mudah diterapkan

b. Mempunyai 2 level (-1 dan 1$)$ dan (0 dan 1)

c. Mempunyai autocorelasi yang tajam untuk memungkinkan sinkronisasi kode.

d. Mempunyai beda jumlah '0' dan '1' hanya satu (one zero balance) untuk memperoleh spectrum density yang bagus.

E. Harga Cross-Corelation yang Rendah yang Berakibat Jumlah Kanal Dalam Satu Pita Frekuensi Semakin Tinggi.

Metode yang digunakan untuk membangkitkan PN code adalah :

- Gold Codes

Gold Codes didapatkan dari proses XOR (modulo 2 adding) dua buah maksimum squence dengan panjang yang sama (kode faktor). Konfigurasi generator Gold Code digambarkan pada Gambar 5.

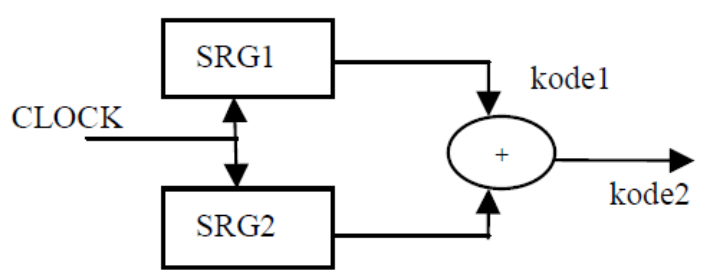

Gambar 5. Konfigurasi Gold Code 
Ilustrasi dari generator Gold Code dapat diperlihatkan dengan Gambar 6.

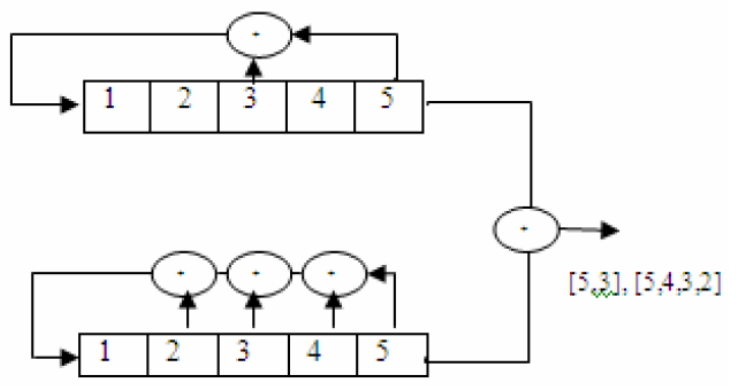

Gambar 6. Ilustrasi Generator Gold Code

Setiap perpindahan posisi fase antara dua generator akan menyebabkan dibangkitkannya kode-kode baru. Generator Gold Code 31 chips ini akan menghasilkan deretan kode sebanyak 33 chip. Kode ini merupakan komposisi yaitu 2 kode berasal dari masing-masing generator dan 31 kode merupakan hasil dari pergeseran komponen yang ada pada sequence. Pada sequence bila dilakukan pergeseran tap maka output bit ke 32 merupakan pengulangan bit awal. Berikut ini akan diberikan contoh pembangkitan Gold Code dari 2 squence yang mempunyai deret kode generator sebanyak 5 stage (2n-1).

\section{METODOLOGI}

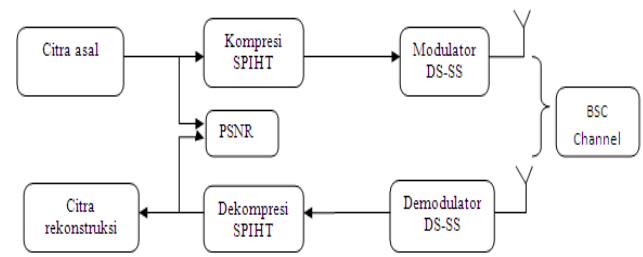

Gambar 7. Blok Diagram Sistem

Gambar 7 menjelaskan bagaimana blok diagram sistem terbentuk. Pertama file citra akan diubah menjadi data digital, dengan ukuran matrik (MXN) sesuai dengan ukuran citra asal, kemudian didekomposisi pada level tertentu dan dilakukan proses encoding sehingga menghasilkan bit-bit biner, setelah itu bit-bit tersebut akan dikirim dengan metode Spread Spectrum Direct Sequences. Dan didekodekan kembali sehingga menghasilkan citra terkompresi dan hasil kompresi tersebut dapat dibandingkan dengan citra asal dengan mengukur nilai PSNR nya.

\section{A. Metode Kompresi Data}

Algoritma kompresi data yang digunakan dalam tugas akhir ini adalah SPIHT (Set
Partitioning In Hierarchical Trees), merupakan algoritma kompresi citra yang mampu mencapai rasio kompresi yang tinggi. Dengan cara mengkodekan koefisien hasil transformasi wavelet secara bertahap, pengkodean berbasis wavelet memberikan perbaikan berarti pada kualitas gambar. Hal tersebut karena sifat pemaketan energi dari alih-ragam wavelet. Energi yang dimaksud dalam pengolahan citra adalah kuadrat nilai-nilai piksel. Serta terjadinya distorsi minimum pada citra terekonstruksi meskipun dilakukan penghilangan koefisien-koefisien alih ragam yang mendekati nol. Gambar 8 adalah blok diagram proses kompresi citra dengan algoritma SPIHT.

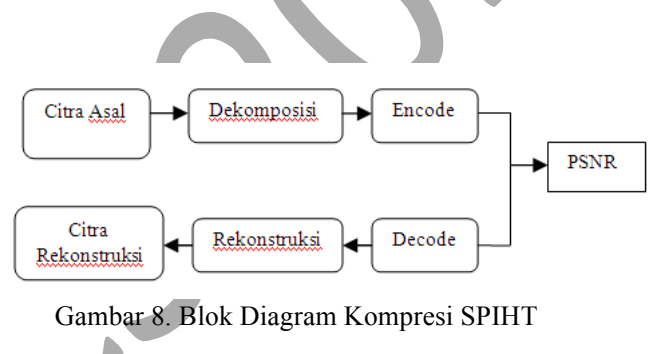

Citra grayscale masukan dibaca dan disimpan dalam sebuah matrik. Matrik citra selanjutnya diolah dalam beberapa proses utama yaitu dekomposisi, kuantisasi, encode, decode, rekonstruksi.

Pertama matrik citra pada proses dekomposisi dibagi menjadi empat buah subband dan didownsample. Empat buah subband mempunyai resolusi yang sama yaitu setengah dari resolusi citra sebelumnya empat buah subband diperoleh dari pemfilteran menggunakan filter vertikal dan horizontal. Dekomposisi dapat dilakukan pada tingkatan tertentu. Proses encode dilakukan dengan memanggil fungsi-fungsi tertentu. Tahap selanjutnya yaitu decode yang mengelola data hasil encode sebagai data masukan. Dan pada tahap rekonstruksi, data akan di rekonstruksi untuk mendapatkan citra hasil yang dibutuhkan.

\section{B. Teknik Transmisi}

Pada tugas akhir ini teknik transmisi yang digunakan adalah Direct Sequence Spread Spectrum (DS-SS), dimana sebuah sinyal ditransmisikan melalui beberapa tahap seperti terlihat pada Gambar 9. Data diperoleh dari tahap encode pada algoritma kompresi data SPIHT. Setelah itu data di spreading oleh Pseudonoise code 
(PN code), PN code yang digunakan pada tugas akhir ini yaitu Gold Code.

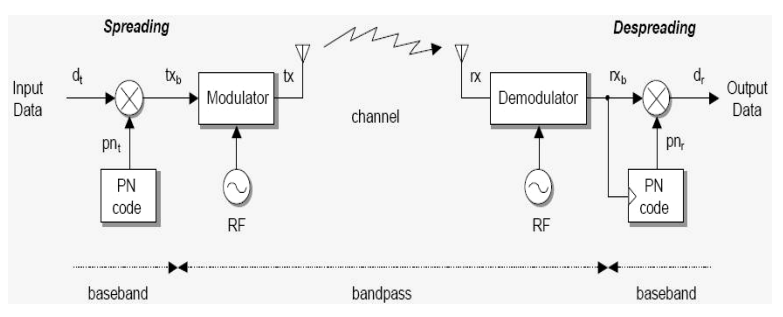

Gambar 9. Blok Diagram Sistem Transmitter

Pada sisi penerima sinyal yang didapatkan masih berupa sinyal acak. Untuk itu dilakukan proses despreading. Tujuannya yaitu untuk mendapatkan sinyal data asli dengan cara mengkorelasikan sinyal tersebar (spreading signal) dengan PN code yang sama dengan yaitu Pseudonoise Gold Code yang digunakan pada pengirim. Gold Code adalah merupakan nonorthogonal code yang merupakan turunan dari MSequence. Gold Code disusun oleh dua buah MSequence yang masing-masing output-nya ditambahkan (adder modulo 2). Kedua output dari M-Sequence ditambahkan (XOR) secara chip per chip menggunakan pulsa-pulsa clock yang sinkron. Disini digunakan 8 shift register, agar kode yang dihasilkan maximal yaitu sebesar 255. Maka taping yang digunakan harus sesuai dengan tabel 2-2, disini kita memakai $[8,7,6,5,2,1]$ dan $[8,7,6,1]$. Tipe taping generator Gold Code seperti terlihat pada Gambar 10.
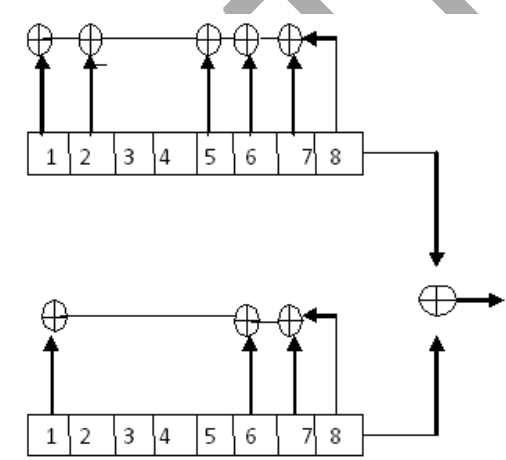

GoldSequence

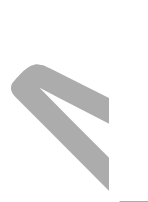

Gambar 10. Tipe Taping Generator Gold Code yang Digunakan

\section{PENGUJIAN DAN ANALISIS}

A. Uji Coba Teknik Kompresi SPIHT dengan kontrol Rate (Bpp)

Tujuan dari uji coba ini adalah melakukan kompresi terhadap sebuah citra gray scale dengan kontrol laju bit bpp, sehingga didapatkan nilai PSNR dan MSE dari hasil kompresi dengan algoritma SPIHT.

Skenario uji coba adalah sebagai berikut: Data citra dibaca dan dilakukan kompresi, sehingga dihasilkan citra hasil kompresi, tahap selanjutnya adalah dilakukan perhitungan terhadap nilai PSNR dengan cara membandingkan citra awal terhadap citra hasil kompresi. Dan berikut ini adalah hasil pengukuran PSNR, MSE, kompresi ratio pada masing-masing citra dengan kontrol bpp. Pemilihan tipe wayelet pada masingmasing citra didasarkan pada penelitian sebelumnya [1]. Nilai PSNR dan MSE terbaik pada kompresi citra lena dilakukan dengan menggunakan tipe wavelet biortogonal 2.4 dan level dekomposisi sebanyak 8. Tabel 1, 2 dan 3 menunjukkan hasil kompresi pada beberapa citra.

TABEL 1. KOMPRESI SPIHT PADA CITRA LENA.BMP

\begin{tabular}{|l|l|l|l|}
\hline rate & PSNR & MSE & Elapsed Time \\
\hline 0.2 & 28.6296 & 89.1494 & 2.8440 \\
\hline 0.4 & 31.9865 & 41.1557 & 3.1400 \\
\hline 0.6 & 34.3104 & 24.1014 & 4.5470 \\
\hline 0.8 & 36.6622 & 14.0237 & 5.4690 \\
\hline 1 & 38.7057 & 8.7602 & 7.4840 \\
\hline 1.2 & 40.4327 & 5.8859 & 8.8430 \\
\hline 1.4 & 41.8004 & 4.2958 & 15.1720 \\
\hline 1.6 & 43.5683 & 2.8592 & 20.0630 \\
\hline 1.8 & 44.6514 & 2.2281 & 21.0780 \\
\hline 2 & 45.8829 & 1.6780 & 28.6250 \\
\hline
\end{tabular}

TABEL 2. KOMPRESI SPIHT PADA CITRA PAPRIKA.JPG

\begin{tabular}{|l|l|l|l|}
\hline rate & PSNR & MSE & Elapsed Time \\
\hline 0.2 & 25.6050 & 178.8888 & 3.3130 \\
\hline 0.4 & 29.8065 & 67.9885 & 3.1720 \\
\hline 0.6 & 32.8046 & 34.0891 & 9.9850 \\
\hline 0.8 & 34.7830 & 21.6161 & 6.2970 \\
\hline 1 & 36.3380 & 15.1107 & 7.2030 \\
\hline 1.2 & 37.7098 & 11.0178 & 9.0780 \\
\hline 1.4 & 38.8826 & 8.4105 & 11.3600 \\
\hline 1.6 & 39.7948 & 6.8171 & 18.1570 \\
\hline 1.8 & 40.6651 & 5.5792 & 20.5150 \\
\hline
\end{tabular}


TABEL 3. KOMPRESI SPIHT BIOR2.4 PADA CITRA BABOON.BMP

\begin{tabular}{|l|l|l|l|}
\hline rate & PSNR & MSE & $\begin{array}{l}\text { Elapsed } \\
\text { Time }\end{array}$ \\
\hline 0.2 & 21.3284 & 478.8952 & 2.0780 \\
\hline 0.4 & 22.5753 & 359.3790 & 3.5780 \\
\hline 0.6 & 23.5410 & 287.7248 & 5.0930 \\
\hline 0.8 & 24.6785 & 221.4263 & 7.6250 \\
\hline 1 & 25.9391 & 165.6429 & 12.9530 \\
\hline 1.2 & 26.8539 & 134.1816 & 17.4840 \\
\hline 1.4 & 27.9612 & 103.9837 & 24.0780 \\
\hline 1.6 & 29.2602 & 77.1017 & 32.3600 \\
\hline 1.8 & 30.5607 & 57.1489 & 43.2500 \\
\hline 2 & 31.5966 & 45.0220 & 40.7970 \\
\hline
\end{tabular}

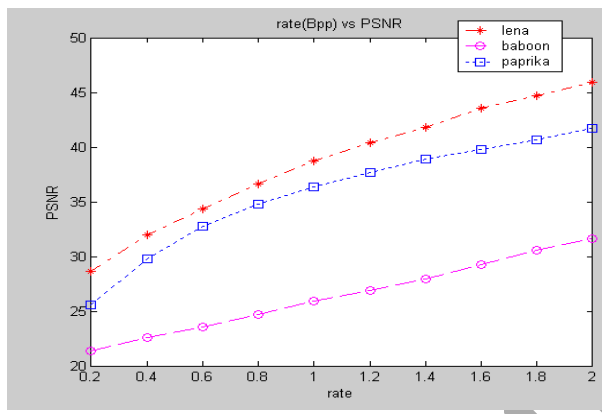

Gambar 11. Grafik Pengaruh Laju Bit Terhadap PSNR

Pada Gambar 11 dapat dilihat bahwa semakin besar nilai laju bit (Bpp) akan semakin besar pula PSNR yang dihasilkan gambar terkompresi dengan teknik SPIHT. Dengan laju bit yang sama citra lena mempunyai nilai PSNR yang paling bagus dibanding citra paprika dan babon. Hal ini dikarenakan citra lena mempunyai frekuensi yang rendah.

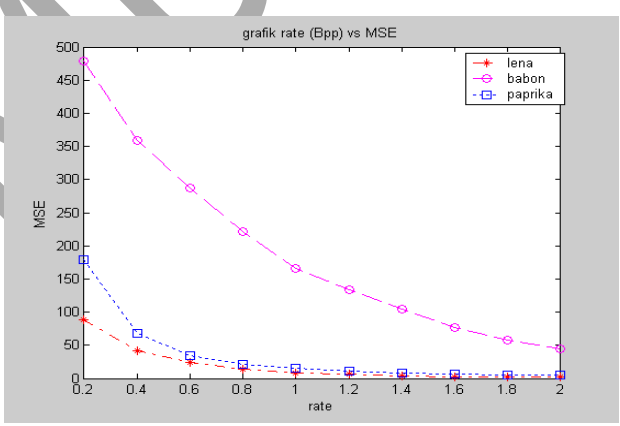

Gambar 12. Grafik Pengaruh Laju Bit Terhadap MSE
Dapat dilihat pada Gambar 12 bahwa semakin besar nilai laju bit (Bpp) akan semakin kecil nilai MSE yang dihasilkan gambar terkompresi dengan teknik SPIHT.

Rate merupakan parameter matematik yang bisa mengkuantifikasi kinerja kompresi. Parameter ini memiliki satuan bpp (bit per pixel). Misalnya, suatu citra asli memiliki ukuran 256 x 256 pixel dengan representasi 8 bit maka kapasitasnya adalah $256 \times 256 \times 8$ bit $=524288$ bit $=65536$ byte atau sekitar 65 kilobyte. Jika parameter ini menunjukkan angka 2,5 bpp maka hal ini menyatakan bahwa citra terkuantisasi akan memililki kapasitas sebesar 256 x $256 \times 2,5=163840$ bit $=20480$ byte atau sekitar 20 kilobyte.

\section{B. Uji Coba Teknik Kompresi SPIHT dengan kontrol Level Dekomposisi.}

Skenario uji coba adalah sebagai berikut: Data citra dibaca dan dilakukan kompresi, sehingga dihasilkan citra hasil kompresi, dan dilakukan perubahan terhadap nilai level dekomposisi. Level dekomposisi yang diberikan untuk pengujian terhadap sistem didasarkan pada penelitian [4]. Tahap selanjutnya adalah dilakukan perhitungan terhadap nilai PSNR dengan cara membandingkan citra awal terhadap citra hasil kompresi. Dan berikut ini adalah hasil pengukuran PSNR, MSE.

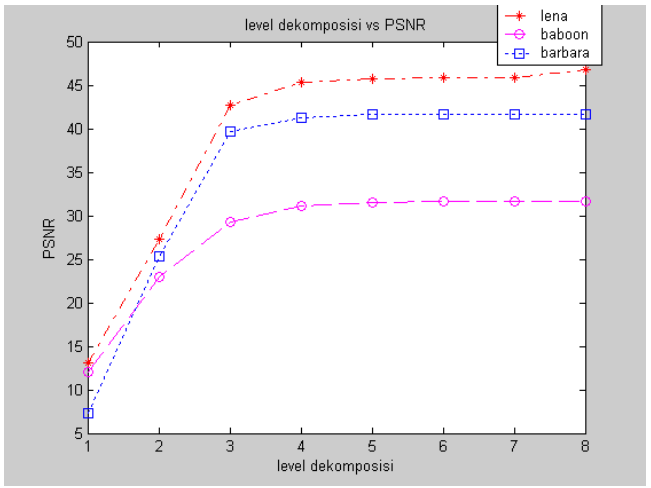

Gambar 13. Grafik Level Dekomposisi VS PSNR

Pada Gambar 13 terlihat bahwa garis bergerak turun pada level awal kemudian bergerak konstan pada level selanjutnya, hal ini berarti bahwa kualitas citra hasil kompresi mengalami penurunan pada level awal, kemudian bernilai konstan pada level selanjutnya 


\section{KESIMPULAN \& SARAN}

\section{A. Kesimpulan}

1. Pada laju kompresi yang sama kompresi citra SPIHT meningkatkan nilai PSNR rata-rata sebesar 1,31 dB untuk citra dengan aktivitas frekuensi rendah (citra Lena), 0,98 dB untuk citra dengan aktivitas frekuensi menengah (citra paprika), dan $0,76 \mathrm{~dB}$ untuk citra dengan aktivitas frekuensi tinggi (citra Baboon). Dengan demikian semakin rendah aktivitas frekuensi citra, kualitas citra rekonstruksi kompresi SPIHT akan semakin baik.

2. Pada Citra berfrekuensi tinggi (baboon) jika dikenakan sebuah kompresi maka akan menghasilkan nilai PSNR hasil kompresi dengan kualitas buruk (poor-picture), karena dari semua citra kompresi yang dihasilkan mempunyai nilai PSNR $\leq 40 \mathrm{~dB}$.

3. Pada level dekomposisi sebanyak 4, nilai PSNR yang dihasilkan pada citra terkompresi mempunyai nilai yang cenderung konstan, dan pertambahan nilai maksimal yang dihasilkan adalah $\leq 0,4 \mathrm{~dB}$.
B. Saran

Pada penelitian selanjutnya penulis menyarankan agar pada saat simulasi proses transmisi data diberikan frekuensi noise untuk mempertimbangkan berapa nilai error code pada saat data dikirim untuk dibandingkan dengan data yang diteima hal ini dilakukan untuk mengetahui PSNR citra pada saat ditransmisikan.

\section{REFERENSI}

[1] M. Agus Zainuddin, Aries Pratiarso, dan Adhi Ddarma Wibawa, "Analisis Kinerja Sistem Transmisi Citra Menggunakan Teknik Diversitas Dengan Umpan Balik LDPC", IES, Nopember 2008

[2] T. Morkel, J.H.P. Eloff, dan M.S. Olivier, "An Overview Of Image Steganography", ICSA Research Group, South Africa, 2005.

[3] Abas Ali Pangera, "Perbandingan FHSS dan DSSS Pada teknologi spread spectrum", STMIK Amikom Jogjakarta 2003.

[4] Said and W.A . Pearlman, "A New Fast and Efficient Image Codec Based on Set Partitioning In Hiearchical Tress" IEEE Trans. Ciecuits and System for Video Technology, Vol. 6, pp.243-250,june 1996. 